Utah State University

DigitalCommons@USU

$5-1951$

\title{
Age and Growth of the Brown Trout Salmo trutta fario Linnaeus in Logan River, Utah
}

\author{
William Sigler \\ Utah State University
}

Follow this and additional works at: https://digitalcommons.usu.edu/etd

Part of the Ecology and Evolutionary Biology Commons

\section{Recommended Citation}

Sigler, William, "Age and Growth of the Brown Trout Salmo trutta fario Linnaeus in Logan River, Utah" (1951). All Graduate Theses and Dissertations. 6353.

https://digitalcommons.usu.edu/etd/6353

This Thesis is brought to you for free and open access by the Graduate Studies at DigitalCommons@USU. It has been accepted for inclusion in All Graduate Theses and Dissertations by an authorized administrator of DigitalCommons@USU. For more information, please contact digitalcommons@usu.edu.

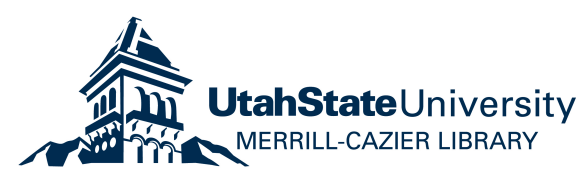


Age and Growth of the Brom Trout Salmo trutta far1o Linnaous in

\author{
Iogan Rivor, Utah \\ W1111am S1glor
}

Dopartmont of W1ldifo lanagoment, Utah Stato Agrioultural Collogo, Logan, Utah

\begin{abstract}
The Logan River flowing southesterly through the mountains of Cache County, Utah is comparatively cold to tho mouth of Logan Canyon. The stream is characterizod by steop gradient, a high volocity and reletively fow pools. A total of 1053 brown trout were exanined during, the course of this study, 286 were retained for age and growth determinations. The body-scalo relationship is $\mathrm{L}=40.46 \mathrm{~mm}$. $+0.4418 \mathrm{kR}$ $+0.01908 R^{2}$ whoro I equals standard longth in m1111moters, and $R$ equals soale radius times 80 . The relationship of standard lensth to woight is described by the formula $w=0.000022 \mathrm{~L}^{2.96}$. The rate of groith in longth of Logan Rivor brown trout is comparablo to that of soverel other populations. The rolative voipht is sorewhat highor.
\end{abstract}

\title{
Int roduction
}

In 1948 a eomprehensivo fishory investigation on Logan River was Initiated by the Dopartment of Wildifo Managenont, Jtah State Agrioulbural Colloge, and tho Utah Cooporative Wild lifo Rosearoh Unit. I 
1. Utah Fish and Game Dopartment, WIIdIfe Management Institute, Utah State AgricuItural College and U.S, Fish and Wild life Service, ooperating.

One phase of this study is the life history of the brown trout Salmo trutte fario Linnaous.

Native fish in Logan River above the lowest impoundment dam inolude outthroat trout Salmo elarki Richardson, mountain whitefish Prosopium williansoni (GIrard), Utah sculpin Cottus bairdi semisoaber (Cope), and rarely the smallfin redside shiner Richardsonius balteatus hydrophlox (Cope). Introduced fish, in addition to the brown trout, are the eastern brook trout Salvelinus fontinalis fontinalis (Mitoheli), and coast rainbow Salmo gairdneri irrideus Gibbons. ${ }^{2}$ There is no up2. Since the introduction of rainbow trout, the hybrid, rainbow $x$ outthroat has appeared.

stroam passage of fish over the lowest impoundment dan.

Fish were oollected largely with the aid of an eleotrio shooking mechine. A few were colleoted with experimental $g^{111}$ nots and by hook and line. A total of 1053 fish were examined during the coursa of this study; 286 zere retained for age and growth determinations. Sealos and other data were taken acoording to standard procedure from June 1948 through Fobruary 1951.

Carlander (1950) lists over 100 artioles and reports which contain some reference to brown trout. However, detalled information on the rate of growth of wild brown trout is quite limited. 
Deseription of the Area

Logan River heads in Franklin County in Southern Idaho and flows southwesterly through Caohe County, Utah, until it empties into Baar River. The rugged mountainous area of the Logan Rivor watershed covers 225 square miles of weathered Paleozole Age limestone, dolomite and shale. The main branch of the river enters Utah at an elovation of 8,500 feet and drops to 4,500 foet where it enters Cache Valley: distance of approximately 36 stream miles. Brown trout are nost abundant below elevations of 6,800 feet. The average gradient for the Logan River is approximately 70 feet per mile (Erown, 1935). In general, the higher elevations have meh steeper gradients than the lower sections of the river. There are three artifiolal impoundments above 4500 feet which supply power and irrigation water to Cache Valley. These impoundments, none of which exceeds 22 feet in depth or 4 acres in size, have a rioh bottom layer of silt and extensive shoal areas.

The stream botton is composed largely of coarse gravel, rubblo, and boulders. Sand and grave $I$ beds are soaroe due to the steop gradient and high velooity of the river. Silting is slight in the stream bed except during the spring run-off. Turbidities, based on silicon dioxide equivalents, range from 25 to 32 parts per million in the spring. but drop to 6 parts per million in September and Octobor. Thare is virtually no pollution except from soli erosion. The average volocity of the river over a series of stations, between Apr11 and Ootober in 1948 and 1949 , was 2.6 feet por second. 
Tablo 1. Body-soalo Relationship (I/So) of 286 Brown Trout from Logan Rivar, Arranfod in 20 Millimotor Standard Ioneth Groups with AlI Ago Groups Combinod.

\begin{tabular}{|c|c|c|c|c|}
\hline $\begin{array}{l}\text { Aotual moan } \\
\text { standard lonfth }\end{array}$ & $\begin{array}{l}\text { Actual moan } \\
\text { scalo measurement }\end{array}$ & $\begin{array}{l}\text { Calculated man } \\
\text { soa lo rad1us }\end{array}$ & If/So & $\begin{array}{l}\text { Humber of } \\
\text { fish }\end{array}$ \\
\hline $\begin{array}{r}51.4 \\
68.6 \\
89.7 \\
113.4 \\
129.6 \\
150.0 \\
170.7 \\
189.5 \\
210.5 \\
229.6 \\
249.6 \\
268.4 \\
293.4 \\
311.0 \\
332.5 \\
384.6\end{array}$ & $\begin{array}{l}19 \\
26 \\
36.6 \\
51.4 \\
53.4 \\
65.0 \\
71.0 \\
82.1 \\
82.8 \\
91.0 \\
92.8 \\
97.1 \\
97.4 \\
103.0 \\
119.5 \\
129.0\end{array}$ & $\begin{array}{l}15 \\
28 \\
40.5 \\
51 \\
50 \\
65 \\
72 \\
77.5 \\
83.5 \\
88.7 \\
94.0 \\
98.3 \\
104.0 \\
108.0 \\
112.7 \\
123.2\end{array}$ & $\begin{array}{l}2.70 \\
2.64 \\
2.45 \\
2.21 \\
2.43 \\
2.31 \\
2.40 \\
2.31 \\
2.54 \\
2.52 \\
2.69 \\
2.76 \\
3.01 \\
3.02 \\
2.78 \\
2.98\end{array}$ & $\begin{array}{r}9 \\
16 \\
11 \\
29 \\
41 \\
35 \\
44 \\
30 \\
25 \\
10 \\
12 \\
8 \\
5 \\
6 \\
2 \\
3\end{array}$ \\
\hline
\end{tabular}

$I=40.46 \mathrm{~mm}+0.44185 R+0.01908 R^{2}$ 
The major source of water during the surmor and fall months is springs, This, coupled with a high water volocity and an abundenoe of bank shade, keeps the temperature comparatively low to the mouth of Logan Canyon. Temperatures taken betwoen April and Ootober, 1948 and 1949, from the Idaho line down to the upper (third) dam, averaged about 48 degrees and did not exeeed 60 . The average monthly moan discharge at the junotion of the Cache National Forest and Cache Valley, besed on the 1946-1949 water seasons, was 247 cuble feet per second. The greatest flow oocurred in lay (717) and the least in February (108).

The habitat of the mountain whitefish, which is similar to that of the brown trout, is deseribed in more detali by Sigler (1952).

\section{Rate of Growth}

The body-scale relationship of 286 brown trout is deseribed by the formula $L=40.46$ ma $+0.44185 R+0.01908 R^{2}$, where $L=$ standard length in millimeters and $R=$ scalo radius in millimoters times 80 (table 1 and figure 1). The assessment of age and the celoulation of growth were accomplishod by reading the seales. The validity of the method was tested according to practices deseribed by Van Oosten (1929) and Hile (1941). Aotual caloulation of past growth was made with the ald of a nomograph sinilar to that deseribed by Carlander and Smith (1944) and Hilo (1950).

Brown trout in Logan River grow approximately three inohes per

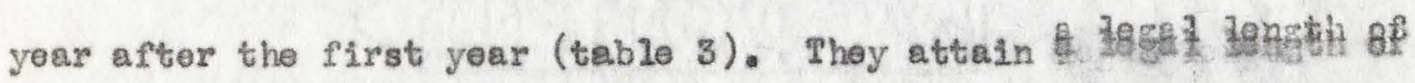
seven inches early in their third year of life. fosording to this 
Tablo 2. Longth-weight Ro latlonship of 286 Brown Trout from Logan River.

\begin{tabular}{|c|c|c|c|c|c|}
\hline $\begin{array}{l}\text { loan } \\
\text { standard } \\
\text { length in } \\
\text { milinoters }\end{array}$ & $\begin{array}{c}\text { Wotaght } \\
\text { moan } \\
\text { moan }\end{array}$ & $\begin{array}{c}\text { In grans } \\
\text { Caloulatod } \\
\text { moan }\end{array}$ & $\begin{array}{c}\text { Difference } \\
\text { In actual \& } \\
\text { os loulated } \\
\text { weight }\end{array}$ & $\begin{array}{l}\text { Loan } \\
\text { X }\end{array}$ & Number of Plsh \\
\hline $\begin{array}{r}51 \\
69 \\
90 \\
123 \\
130 \\
250 \\
272 \\
190 \\
210 \\
230 \\
250 \\
260 \\
293 \\
321 \\
332 \\
335\end{array}$ & $\begin{array}{r}2 \\
6 \\
12 \\
25 \\
40 \\
62 \\
90 \\
127 \\
170 \\
204 \\
267 \\
329 \\
400 \\
512 \\
084 \\
868\end{array}$ & $\begin{array}{r}2 \\
6 \\
18 \\
26 \\
40 \\
61 \\
90 \\
222 \\
165 \\
215 \\
276 \\
339 \\
440 \\
526 \\
638 \\
989\end{array}$ & $\begin{array}{r}0 \\
0 \\
+1 \\
+1 \\
0 \\
-1 \\
0 \\
-5 \\
-5 \\
+12 \\
+9 \\
+10 \\
+40 \\
+14 \\
41 \\
+121\end{array}$ & $\begin{array}{l}2.938 \\
1.912 \\
1.720 \\
2.737 \\
2.842 \\
1.845 \\
1.824 \\
1.860 \\
1.884 \\
1.688 \\
1.728 \\
1.692 \\
1.574 \\
1.712 \\
1.347 \\
1.546\end{array}$ & $\begin{array}{r}9 \\
26 \\
21 \\
29 \\
41 \\
35 \\
44 \\
30 \\
25 \\
10 \\
12 \\
8 \\
5 \\
6 \\
2 \\
8\end{array}$ \\
\hline
\end{tabular}

$W=0.000022 L^{2} \cdot 96$ 
study. fish in advanced year groups do not grow faster than those in younger groups, but simply live longer. Based on age, Logan RIver brown trout apparently grow in length at about the same rate as many other populations (Bddy and Carlander, 1939, Bean, 1902, and others).

A series of one-tenth mile sections of straan were sampled with an lectric shocking machine. A total of 1053 fish from these sections were measured to the nearest inch and recorded on a length-frequency basis. Normally the numbers of fish in length groups decrease as the size of the fish inorease. Fish less than four inches long ropresented only eight percent of the total, and did not follow the expeoted lengthfrequency ratio. This is believed to be a sampling bias rather than a ropresentation of actual conditions. The number of $f$ ish in length groups between 7 and 20 inohes dropped steadily and rapid ly as the size inoreased. Forty-seven pereent of the legal-sized fish were less then 10 inches long, and 61 percent of them were less than 15 inches long. Fish between 4 and 9.7 inches long in the age and growth sample (table 3) represent 95 percent of the total: fish from these same length groups total 76 pereent of the entire population studied. The eonversion fectors, based on the $\mathrm{fish}$ in table one, are as follows: standard length tines total length equals 1.173 ; total length times standard length equels 0.852 ; fork length times standard length equa 180.887 .

\section{length-Weight Re lationship}

The rolationship of wight in grams to standard longth in milli- 
Tablo 3. Sumary of the Lean Caloulatod Standard Longths and Annue Inorements of Lengths in Millimeters for the Logan River Brown Trout with Sexes Combined, Collected in 1948, 1949, and 1950.

\begin{tabular}{|c|c|c|c|c|c|c|c|c|c|c|}
\hline \multirow[t]{2}{*}{ Age class } & \multirow{2}{*}{$\begin{array}{l}\text { Number } \\
\text { of fish }\end{array}$} & \multirow{2}{*}{$\begin{array}{l}\text { Standard } \\
\text { longth } \\
\text { at eapture }\end{array}$} & \multicolumn{8}{|c|}{ Calculated lengths at end of year of lifo } \\
\hline & & & 1 & 2 & 3 & 4 & 5 & 6 & 7 & 8 \\
\hline$I$ & 124 & 238.7 & 86 & & & & & & & \\
\hline II & 92 & 188.8 & 88 & 149 & & & & & & \\
\hline III & 32 & 255.9 & 91 & 255 & 218 & & & & & \\
\hline IV & 6 & 326.0 & 72 & 128 & 2012 & 269 & & & & \\
\hline $\mathrm{v}$ & 2 & 395.5 & 75 & 128 & 269 & 253 & 317 & & & \\
\hline VI & 1 & 420.0 & 62 & 116 & $18 \varepsilon$ & 240 & 300 & 372 & & \\
\hline VII & 1 & 670.7 & 84 & 124 & 270 & 270 & 404 & 470 & 600 & \\
\hline VIII & 2 & 654.5 & 79 & 119 & 211 & 252 & 341 & 377 & 528 & 600 \\
\hline \multicolumn{3}{|c|}{$\begin{array}{l}\text { Grand averages } 260 \\
\text { and total }\end{array}$} & 87 & 148 & 211 & 262 & 337 & 399 & 552 & 600 \\
\hline \multicolumn{3}{|c|}{ Inerements of growth } & 87 & 61 & 64 & 70 & 82 & 52 & 144 & 72 \\
\hline \multicolumn{3}{|c|}{ Equivalent total longth in inehes } & 4.0 & 2.8 & 2.9 & 3.2 & 3.8 & 2.4 & 6.6 & 3.3 \\
\hline \multicolumn{3}{|c|}{ Number of fish } & 260 & 136 & 44 & 12 & 6 & 4 & 3 & 2 \\
\hline \multicolumn{3}{|c|}{ Equivalent tota 1 length in inches } & 4.0 & 6.9 & 9.7 & $12 \cdot 2$ & 25.6 & 28.3 & 25.5 & 27.7 \\
\hline
\end{tabular}


meters is deseribed by the formula $W=0.000022 L^{2.96}($ table 2$)$. The agreement between actual and calculated woights is good for groups of fish containing over six inilvirinels. The weight inoreases approximate ly as the 2.96 power of the length of the fish. Sohuok (1942) gives a somewhat lower value for wild brown trout from New York. Howaver, this in part is accounted for by the fact that the total length was used instead of standard length in calculating the formula,

The condition factor, $\mathrm{X}$, of brown trout from Logan River was calculated from the following $K=\frac{W \times 10^{5}}{L^{3}}$; when w equals weight in grams, and $L$ equals standard length in millimeters. The highest $K$ value of 1.938 was recorded for the smallest fish: K decroeses somewhat with the incraase in length. The oondition factor of the Logan River fish is somewhat higher than that of several other populations. (Sohuck, 1945, Carlander, 1944).

Aocording to Noedham (2938) fow brown trout over five pounds are taken from streams. Bean (1902) lists as maximum a woight of 22 pounds and a longth of 35 inches, but states that 5 or 6 pounds is a good average. Although Logan River has ylelded some very largo brown trout, Including the world's reoord, accurate data on them are scarce. In 1929 a 39 Inoh brown trout weighing 35 pounds was taken from the lowe st impoundment. Almost every year two or more ranging in woight from 12 to 18 pounds are caught from the lower part of the river.

\section{Acknowledgements}

I an grateful for the assistance recoived from graduate and undergraduate students in the department of Wyldife Management, Utah State 
Agricultural College. Speolal thanks are due to students Sam Jackson and Goorge Fleoner. 


\section{IAterature Cited}

Bean, T. H, 1902, Food and game fishes of New York, N, Y, Forest, Fish and Game Comm. Rept. $7: 251-460$. Brown, C.J.D. 1935. A survey of the waters of the Cache National Forest, Utah. Mimeographed materia2, U.S. Bur. Fish. 34 pp. Carlander, Kenneth D. 1944. Notes on the oveffieient of condition, K, of Minnesota fishos. Minn. Bur. Fish. Res. Invest. Rept. 41. revised, $40 \mathrm{pp}$. typed.

Car iander, Kennoth D. 1950, Handbook of froshwater fishery biolozy. Wm. C. Brown Co, Dubuque, Iowa. $282 \mathrm{pp}$.

Carlander, Kennoth D. and Lloyd $L_{0}$ Smath, Jre 1944. Some uses of nomographs in flsh growth studies. Copeia. 3:157-162.

Eddy, Samue1, and Kennoth D. Carlander. 1939. Grouth of Minnesota fishes. Minn. Conservationist $69: 8-10$.

Hi 10. Ralph. 1941. Ago and growth of the rook bass Ambloplites rupestris (Rafinosque) in Nebish Lake, Wisconsin. Trans, Wise. Aoad. Sel. Arts and Lot. $33: 189-337$.

H1 10, Ralph. 1950. A nomograph for the computation of the growth of fish Prom sealo measurements. Trans. Amer. Fish. Soe. 78:156-162. Noodham, James G. 1938. Irout streams. Comstock Pub 1. Co. Ithaca, N.Y. 233 pp. Soluck. Howard A. 1942. The effect of jaw-tagging upon the oondition of trout. Copeia $1942(1): 333-39$.

Schuck, lloward A, 2945. Surviva 1, population density, growth, and movement of the wild brom trout in Crystal Crook. Trans. Am. Fish. Soc. $73: 209-230$. 
Siglor. William F. 1951. The lifo history and management of the mountain wistefish Prospopium williamsoni (Girard) in Iogan Fivor, Utah. Utah figr. Exp. Sta. Bul. In pross.

Van ooston. John. 1929. Iife history of the lake horring (Iouoiohthys artedi Io Sueur) of lake huron as revealed by its scales, with a critique of the 800 le mothod. Eul. U.S. Bur. Fish 44 (Doo. 1053 ) : $265-428$. 